\title{
A Radio-Immunoassay of 19-Nortestosterone Using Celite Column Chromatography
}

\author{
By Anneke M. G. Bosch \\ Organon Scientific Development Group, Oss, The Netherlands
}

(Received July 4/October 3, 1983)

\begin{abstract}
Summary: In order to measure plasma or serum concentrations of 19-nortestosterone (nandrolone), a radioimmunoassay has been developed using $\mathrm{C} 7$-tritium labelled nandrolone and antisera raised against nandrolone 3-(O-carboxymethyl)oxime-albumin. Because these antisera displayed considerable cross-reactions towards testosterone, $5 \alpha$-dihydrotestosterone and $5 \alpha$-dihydronandrolone, it proved to be necessary to separate nandrolone from these cross-reacting steroids prior to the radio-immunoassay. Using Celite/ethylene glycol columns a complete separation could be achieved between nandrolone and these cross-reacting steroids. The assay procedure involved extraction with ethyl acetate, chromatography on Celite/ethylene glycol columns, overnight incubation of samples and standards with antiserum and labelled compound, bound/free separation with dextran-coated charcoal and counting of the supernatant in a liquid scintillation counter.
\end{abstract}

Recoveries for the total assay procedure (expressed as fractions) were between 0.85 and 1.01 . The assay displayed a sensitivity of $0.7 \mathrm{nmol} / 1$ (at $50 \%$ binding) or $0.2 \mathrm{nmol} / \mathrm{l}$ (at $80 \%$ binding), while the within-assay and from day to day coefficients of variation were $9.8 \%(n=114)$ and $12.9 \%(n=13)$ respectively for duplicate measurements.

\section{Radioimmunassay von 19-Nortestosteron nach Säulenchromatographie an Celit}

Zusammenfassung: Zur Bestimmung der Konzentration von 19-Nortestosteron (Nandrolon) in Plasma oder Serum wurde ein Radioimmunassay entwickelt. Dazu wurden am C-Atom 7 mit Tritium markiertes Nandrolon und gegen Nandrölon-3-(O-carboxymethyl)-oxim-Älbumin erzeugte Antiseren verwendet. Weil diese Antiseren beträchtliche Kreuzreaktionen gegenüber Testosteron, $5 \alpha$-Dihydrotestosteron und $5 \alpha$-Dihydronandrolon zeigten, erwies es sich als erforderlich, Nandrolon vor dem Radioimmunassay von diesen kreuzreagierenden Steroiden zu trennen. Mit Celit/Ethylenglykol-Säulen konnte eine völlige Trennung von Nandrolon und diesen kreuzreagierenden Steroiden erzielt werden. Das Bestimmungsverfahren umfaßte Extraktion mit Ethylacetăt, Chromatographie an Celit/Ethylenglykol-Säulen, Inkubation von Proben und Standards mit Antiserum und markierter Verbindung über Nacht, Trennung von freiem und gebundenem Tracer mit Dextrạnbešchichteter Aktivkohle und Zählung im Überstand mit einem Flüssigszintillationszähler.

Als Wiederfindung über das Gesamtverfahren ergaben sich Anteile zwischen 0,85 und 1,01. Die Bestimmung zeigte eine Empfindlichkeit von 0,7 nmol/1 (bei 50\% Bindung) oder 0,2 nmol/1 (bei 80\% Bindung), während die Variationskoeffizienten der Doppelbestimmungen in der Serie 9,8\% $(\mathbf{n}=114)$ und von Tag zu Tag $12,9 \%(n=13)$ betrugen.

\section{Introduction}

In order to measure plasma or serum concentrations of 19-nortestosterone (nandrolone), which is widely used therapeutiçally, a radio-immunoassay for this compound has been developed. Antisera were raised against conjugates of bovine serum albumin with nandrolone 3-(O-carboxymethyl)oxime and $11 \alpha-$ hydroxy-nandrolone 11-hemisuccinate, based on 
previous studies on the specificity of antisera against testosterone-albumin conjugates (1). Considerable cross-reactions, however, were found towards testosterone, dihydrotestosterone and dihydronandrolone. Therefore, nandrolone was separated from these cross-reacting compounds on Celite/ethylene glycol columns prior to the radio-immunoassay procedure. The specificity, recovery, sensitivity and reproducibility of the assay are discussed. A summary of this work has been published earlier (2).

\section{Materials and Methods}

\section{Reagents}

Testosterone; 17 $\beta$-hydroxy-19-nor-4-androsten-3-one (nandrolone); androst-4-ene-3,17-dione; $17 \alpha$-hydroxy-androst-4-en-3-

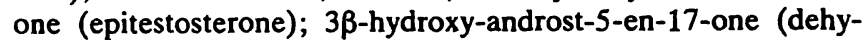
droepiandrosterone); androst-5-ene-3 $\beta, 17 \beta$-diol; $17 \beta$-hydroxy$5 \alpha$-androstan-3-one (dihydrotestosterone); $17 \beta$-hydroxy-5 $\alpha$-androstane-3 $\alpha, 17 \beta$-diol; $5 \alpha$-androstane- $3 \beta, 17 \beta$-diol were from $\mathrm{Di}$ osynth International $B_{i} V_{i}$., Oss. Oestr-4-ene-3,17-dione; oestr-5ene-3 $\beta, 17 \beta$-diol; $17 \beta$-hydroxy-5 $\alpha$-oestran-3-one; $5 \beta$-oestrane$3 \alpha, 17 \beta$-diol; $5 \alpha$-oestrane-3 $\beta, 17 \beta$-diol were synthesized by Mr. J. $S$. Favier and $M$. A. J. van den Broek in the Organon Research Laboratories at Oss, the Netherlands. $\left[7-{ }^{3} \mathrm{H}\right]$ Nandrolone (specific activity $1.07 \mathrm{TBq} / \mathrm{mmol}$ ) was prepared at the Radiochemical Centre, Amersham, U.K. Bovine serum albumin, Cohn fraction V, was from Armour, Eastbourne, U.K.; Norit A was from Sigma Chemical Co., St. Louis, Mo., USA; Dextran T-70 was obtained from Pharmacia Fine Chemicals Ltd., Uppsala, Sweden; Celite (Analytical Filter Aid) was from BDH Chemicals Ltd., Poole, Dorset, U.K.

Isooctane (analytical grade), ethyl acetate (analytical grade), ethylene glycol (analytical grade), were from Merck, Darmstadt, Germany. These solvents were used without further purification. Insta-gel was from Packard Instruments Co.

\section{Assay buffer}

The buffer used throughout the assay was a $0.02 \mathrm{~mol} / \mathrm{h}$ sodium phosphate buffer $\mathrm{pH} 7.0$ containing $0.02 \mathrm{~mol} / \mathrm{l}$ sodium chloride, $0.005 \mathrm{~mol} / \mathrm{l}$ ethylene diamine tetraacetate disodium salt, $0.1 \mathrm{~g} / \mathrm{l}$ merthiolate and $0.15 \mathrm{mmol} / \mathrm{l}$ bovine serum albumin.

Preparation of nandrolone-bovine serum albumin conjugates

Nandrolone 3-(O-carboxymethyl)oxime and $11 \alpha$-hydroxy-nandrolone 11-hemisuccinate were synthesized by Mr. N.P. van Vliet in the Organon Research Laboratories at Oss. This synthesis was similar to that reported for testosterone (1).

Nandrolone-bovine serum albumin conjugates were prepared according to a modification of the mixed anhydride method of $\mathbf{E r}$ langer (3), using $59 \mathrm{~mol}$ of steroid per mol of bovine serum àlbumin. The number of steroid residues per bovine serum albumin molecule was estimated either spectrophotometrically or by amino-group determination with trinitrobenżene sulphonic acid (4).

Preparation of antisera against nandrolone-bovine serum albumin conjugates

Antisera against nandrolone-bovine serum albumin conjugates were prepared in rabbits by three intramuscular injections with $0.25 \mathrm{mg}$ immunogen in complete (1st injection) and incomplete (subsequent injections) Freund's adjuvant at 14-day intervals, followed two weeks after the last injection by an intravenous booster dose of $0.25 \mathrm{mg}$ of the immunogen in physiological saline.

Another booster dose was given four weeks after the second booster injection. If the titre was too low a third booster dose was given four weeks after the previous one.

\section{Extraction of plasma or serum samples}

Plasma or serum samples $(1 \mathrm{ml})$ were diluted with $1 \mathrm{ml}$ assay buffer, followed by addition of $4 \mathrm{ml}$ ethyl acetate. After mixing, the ethyl acetate (upper) phase was separated by centrifugation (1 $\min ; 4900 \mathrm{~N} / \mathrm{kg}$ ) and transferred to siliconized conical test tubes. This extraction step was repeated and the combined ethyl acetate extracts evaporated in a waterbath at $25^{\circ} \mathrm{C}$ under nitrogen. After evaporation the wall of each tube was rinsed with $1 \mathrm{ml}$ isooctane and dried again under nitrogen. All extractions were performed in duplicate.

\section{Celite column chromatography}

\section{Pretreatment of the Celite}

Prior to use, the Celite was stirred with 5 volumes $6 \mathrm{~mol} / 1 \mathrm{HCl}$ for $24 \mathrm{~h}(5)$. The very fine particles and excess of $\mathrm{HCl}$ were removed by washing the Celite with 5 volumes distilled water and decantation of the supernatants. This washing procedure was repeated three times. Subsequently, the Celite was washed with distilled water on a Büchner filter until a $\mathrm{pH}$ of $6=8$ was reached. This was followed by washings with ethanol and ethyl acetate respectively. Finally, the Celite was sucked to dryness and heated overnight in an oven at $600^{\circ} \mathrm{C}$. The activated Celite could then be stored at room temperature for an unlimited period of time.

\section{Preparations of Celite/ethylene glycol columns}

The activated Celite was mixed with ethylene glycol $(2+1$ by weight) in a mortar until a homogeneous mixture was obtained. Because this Celite/ethylene glycol mixture is hygroscopic, the mixture was stored in a desiccator over phosphorus pentoxide for at the most one week.

Five-ml disposạble graduated pipettes wère siliconized and tightly packed with the Celite/ethylene glycol mixture to a height of 5.5 $\mathrm{cm}$. About $0.8 \mathrm{~g}$ of this mixture was used per column. The packed columns were washed with $3 \mathrm{ml}$ isooctane to ensure uniformity and to clear air bubbles from the columns.

\section{Chromatography of serum or plasma extracts}

The dry residues of the ethyl acetate extraction were dissolved in $200 \mu \mathrm{l}$ isooctane and transferred to the Celite/ethylene glycol columns. The test tubes were rinsed three times with $200 \mu \mathrm{l}$ isooctane, which was also transferred to the columns. The columns, with samples applied, were then washed with $21.4 \mathrm{ml}$ of a mixture of $1 \mathrm{ml}$ ethyl acetate and $99 \mathrm{ml}$ isooctane. In this fraction both dihydrotestosterone $(1-10 \mathrm{ml})$ and testosterone $(11-21.4 \mathrm{ml})$ were eluted. Subsequently, nandrolone was eluted with $6 \mathrm{ml}$ of a mixture of $10 \mathrm{ml}$ ethyl acetate and $90 \mathrm{ml}$ isooctane and this fraction collected in siliconized conical test tubes. The nandrolone fraction was evaporated in a waterbath at $25^{\circ} \mathrm{C}$ under nitrogen. The tube walls were rinsed with $1 \mathrm{ml}$ isooctane, which was also evaporated to dryness. The dry residues were dissolved in assay buffer by shaking, incubation for $15 \mathrm{~min}$ in a waterbath at $40^{\circ} \mathrm{C}$ and shaking again.

\section{Radio-immunoassay procedure}

Serial dilutions of sámples and standard (range: 0.04-3.65 $\mathrm{nmol} / \mathrm{l}$ ) were prepared in triplicate with a Dilumatik (Braun, Melsungen, West Germany) followed by the addition of antiserum and label with a Hamilton repeating dispenser. 
The following reagents were pipetted into radio-immunoassay tubes:

- $200 \mu \mathrm{l}$ sample or standard diluted with assay buffer

- $200 \mu \mathrm{l}$ assay buffer

$-100 \mu \mathrm{l}$ antiserum

- $100 \mu \mathrm{l}$ of assay buffer containing $\left[{ }^{3} \mathrm{H}\right]$ nandrolone $(0.15 \mathrm{pmol})$ and incubated for $16 \mathrm{~h}$ at room temperature.

Bound/free separation was accomplished by incubation with $1 \mathrm{ml}$ dextran-coated charcoal suspension, containing $0.5 \mathrm{~g}$ Norit $\mathrm{A}$ and $0.05 \mathrm{~g}$ Dextran T40 per liter assay buffer (without bovine serum albumin), for $15 \mathrm{~min}$ at room temperature. After this incubation the tubes were centrifuged for $10 \mathrm{~min}$ at $19600 \mathrm{~N} / \mathrm{kg}$. An aliquot of $1.0 \mathrm{ml}$ of the supernatant was then mixed with $9.0 \mathrm{ml}$ Instagel and counted in a Liquid Scintillation Spectrometer, model 3375 (Packard), with a tritium efficiency of $30 \%$. Background counts were subtracted automatically.

The results were calculated as described earlier (1).

\section{Results}

\section{Specificity of antisera}

In order to obtain specific antisera, nandrolone 3(O-carboxymethyl)oxime and $11 \alpha$-hydroxy-nandrolone 11-hemisuccinate were coupled to bovine serum albumin. Coupling via $\mathrm{C} 3$ and $\mathrm{C} 11$ was chosen on the basis of results obtained with testosterone antisera (1). Cross-reactions towards related steroids are given in table 1 . These cross-reactions were measured according to Abraham (6) for one antiserum against $11 \alpha$-hydroxy-nandrolone 11-hemisuccinate conjugate and two antisera against nandrolone 3-(Ocarboxymethyl)oxime conjugate. All antisera gave cross-reactions with testosterone, dihydrotestosterone and dihydronandrolone. There was not much difference in specificity between the two types of antisera, especially with regard to their cross-reactions towards testosterone. For this reason, and in view of its titre, the antiserum against the oxime conjugate (R130-T) was chosen for further experiments.

\section{Separation of nandrolone and cross-react-} ing steroids

As the nandrolone antisera displayed considerable cross-reactivity towards testosterone, dihydrotestosterone and dihydronandrolone, a separation step between nandrolone and these cross-reacting steroids was essential. For this separation step Celite columns with ethylene glycol as a mobile phase were used. Elution was performed with isooctane/ethyl acetate. Tritiated nandrolone and testosterone were used to monitor this separation. The separation between nandrolone and testosterone proved to be markedly affected by the humidity of the column mixture, as
Tab. 1. Cross-reactivities of antisera to nandrolone 3-(Ocarboxymethyl)oxime-bovine serum albumin (R130-T, R131-T) and 11 $\alpha$-hydroxy-nandrolone 11-succinylbovine serum albumin (R134-T).

\begin{tabular}{|c|c|c|c|}
\hline Chemical (trivial) name & $\begin{array}{l}\text { R130-T } \\
(1: 6500)\end{array}$ & $\begin{array}{l}\text { R131-T } \\
(1: 4000)\end{array}$ & $\begin{array}{l}\text { R134-T } \\
(1: 700)\end{array}$ \\
\hline $\begin{array}{l}\text { 17 } \beta \text {-Hydroxy-4-oestren-3-one } \\
\text { (nandrolone) }\end{array}$ & 100 & 100 & 100 \\
\hline Oestr-4-ene-3,17-dione & 0.9 & 0.6 & 0.7 \\
\hline Oestr-5-ene-3 $\beta, 17 \beta$-diol & 0.7 & 1.4 & 0.4 \\
\hline $17 \beta$-Hydroxy-5 $\alpha$-oestran-3-one & 34 & 36 & 22 \\
\hline $5 \alpha$-Oestrane- $3 \beta, 17 \beta$-diol & 1.8 & 5.0 & 0.8 \\
\hline $5 \beta$-Oestrane-3 $\alpha, 17 \beta$-diol & 2.0 & 0.5 & 0.6 \\
\hline $\begin{array}{l}\text { 17 } \beta \text {-Hydroxy-androst-4-en-3-one } \\
\text { (testosterone) }\end{array}$ & 28 & 15 & 66 \\
\hline Androst-4-ene-3,17-dione & 1.7 & 0.3 & 0.7 \\
\hline $\begin{array}{l}17 \alpha \text {-Hydroxy-androst-4-en-3-one } \\
\text { (epitestosterone) }\end{array}$ & 0.2 & 0.1 & 0.8 \\
\hline $3 \beta$-Hydroxy-androst-5-en-17-one & 0.1 & 0.1 & 0.04 \\
\hline Androst-5-ene- $3 \beta, 17 \beta$-diol & 0.4 & 0.4 & 0.04 \\
\hline $17 \beta$-Hydroxy- $5 \alpha$-androstan-3-one & 28 . & 18 & 33 \\
\hline $5 \alpha$-Androstane- $3 \alpha, 17 \beta$-diol & 1.7 & 0.3 & 2.1 \\
\hline $5 \alpha$-Androstane- $3 \beta, 17 \beta$-diol & 1.5 & 1.5 & 1.1 \\
\hline Nandrolone phenyl propionate & 0.4 & 0.2 & 0.7 \\
\hline Nandrolone decanoate & 1.0 & 0.6 & 0.6 \\
\hline
\end{tabular}

well as by the percentage ethyl acetate in the elution solvent. With air-dried column mixtures, stored in an open container, a considerable variation in the elution patterns was observed: in general, the steroid fractions were eluted earlier than with column mixtures stored in a desiccator over phosphorus pentoxide.

Increasing percentages ethyl acetate in the elution solvent proved to accelerate the elution of both testosterone and nandrolone. At the same time, however, an increasing overlap was observed between these two fractions.

A complete separation could be achieved with a column mixture stored in a desiccator over phosphorus pentoxide and elution with a mixture of $1 \mathrm{ml}$ ethyl acetate and $99 \mathrm{ml}$ isooctane.

The elution volume of nandrolone could be reduced considerably by using a higher ethyl acetate concentration. In the final assay system therefore the testosterone fraction was collected first, followed by a subsequent elution of the nandrolone fraction with a mixture of $10 \mathrm{ml}$ ethyl acetate and $90 \mathrm{ml}$ isooctane. 
The adequacy of the separation step was checked by assaying $1 \mathrm{ml}$ of a mixture of the main cross-reacting compounds in buffer, containing 69.4 pmol testosterone, $69.0 \mathrm{pmol}$ dihydrotestosterone and $72.5 \mathrm{pmol}$ dihydronandrolone. In the nandrolone fraction an amount of steroid corresponding to $2.7 \mathrm{pmol}$ nandrolone was found, which means that only $1.25 \%$ of the cross-reacting steroids was eluted in the nandrolone fractions.

\section{Recovery}

The recovery of the extraction was checked by adding various amounts of both tritiated and unlabelled nandrolone to buffer. As can be seen from the results of table 2 the recoveries were almost quantitative. Tritiated nandrolone was also added to plasma. After extraction and counting, the fraction of added tritiated nandrolone was 1.01 .

Tab. 2. Recovery of tritiated and unlabelled nandrolone from buffer and plasma after extraction.

\begin{tabular}{|c|c|c|}
\hline & $\begin{array}{l}\text { Recovery } \\
\text { (fraction) } \\
\pm S D\end{array}$ & \\
\hline \multicolumn{3}{|l|}{ Buffer } \\
\hline $\begin{array}{l}+0.91 \mathrm{nmol} / \mathrm{l}\left[{ }^{3} \mathrm{H} \mid \text { nandrolone }(0.25 \mu \mathrm{g} / \mathrm{l})\right. \\
+3.65 \mathrm{nmol} / \mathrm{l}\left|{ }^{3} \mathrm{H}\right| \text { nandrolone }(1.0 \mu \mathrm{g} / \mathrm{l}) \\
+9.13 \mathrm{nmol} / \mathrm{l}\left[{ }^{3} \mathrm{H} \mid \text { nandrolone }(2.5 \mu \mathrm{g} / \mathrm{l})\right.\end{array}$ & $\begin{array}{l}1.24 \\
1.03 \\
0.98\end{array}$ & $\begin{array}{l}(\mathrm{n}=1) \\
(\mathrm{n}=1) \\
(\mathrm{n}=1)\end{array}$ \\
\hline \multicolumn{3}{|l|}{ Buffer } \\
\hline $\begin{array}{ll}+0.91 \mathrm{nmol} / \mathrm{l} & \text { nandrolone }(0.25 \mu \mathrm{g} / \mathrm{l}) \\
+3.65 \mathrm{nmol} / \mathrm{l} & \text { nandrolone }(1.0 \mu \mathrm{g} / \mathrm{l}) \\
+9.13 \mathrm{nmol} / \mathrm{l} & \text { nandrolone }(2.5 \mu \mathrm{g} / \mathrm{l})\end{array}$ & $\begin{array}{l}0.85 \pm 0.10 \\
0.96 \pm 0.11 \\
0.99 \pm 0.02\end{array}$ & $\begin{array}{l}(\mathrm{n}=3) \\
(\mathrm{n}=3) \\
(\mathrm{n}=3)\end{array}$ \\
\hline \multicolumn{3}{|l|}{ Plasma } \\
\hline$+0.36 \mathrm{nmol} / \mathrm{l}\left[{ }^{3} \mathrm{H}\right]$ nandrolone $(0.1 \mu \mathrm{g} / \mathrm{l})$ & $1.01 \pm 0.08$ & $(n=3)$ \\
\hline
\end{tabular}

The recovery of the whole test procedure was, in the first instance, tested with tritiated nandrolone dissolved in assay buffer. For a sample determined in sixfold, the mean value of the fraction recovered was 0.87 (see tab. 3). More or less the same experiment was performed with unlabelled nandrolone added to assay buffer in a concentration of $3.65 \mathrm{nmol} / \mathrm{l}$. As is shown from table 3 the mean value of the fraction recovered was $0.84(n=7)$.

Recoveries (expressed as fractions) of various amounts of nandrolone added to a plasma pool, $(1.82-14.60 \mathrm{nmol} / \mathrm{l})$, as well as the recovery from a standard pool containing a fixed amount of nandrolone, were between 0.85 and 1.01 (see tab. 3).
Tab. 3. Recovery of tritiated and unlabelled nandrolone from normal human plasma after extraction and Celite column chromatography.

Recovery
(fraction)

\pm 士\$̣D

\begin{tabular}{llll} 
A. Buffer & & & \\
$+3.65 \mathrm{pmol}$ & $\left.{ }^{3} \mathrm{H}\right]$ nandrolone $(1.0 \mathrm{ng})$ & $0.87 \pm 0.10 \quad(\mathrm{n}=6)$ \\
$+3.65 \mathrm{pmol}$ & nandrolone $(1.0 \mathrm{ng})$ & $0.84 \pm 0.18 \quad(\mathrm{n}=7)$ \\
& & & \\
B. Plasma & & & \\
$+1.82 \mathrm{pmol}$ & nandrolone $(0.5 \mathrm{ng})$ & $1.01 \pm 0.14 \quad(\mathrm{n}=4)$ \\
$+3.65 \mathrm{pmol}$ & nandrolone $(1.0 \mathrm{ng})$ & $0.95 \pm 0.04 \quad(\mathrm{n}=4)$ \\
$+7.30 \mathrm{pmol}$ & nandrolone $(2.0 \mathrm{ng})$ & $0.89 \pm 0.14 \quad(\mathrm{n}=4)$ \\
$+14.60 \mathrm{pmol}$ & nandrolone $(4.0 \mathrm{ng})$ & $0.85 \pm 0.17 \quad(\mathrm{n}=4)$ \\
& & $1.00 \pm 0.15 \quad(\mathrm{n}=4)$ \\
\hline
\end{tabular}

\section{Sensitivity}

In order to improve the sensitivity of the assay system, which was rather low at the initial antiserum dilution of 1:3500 (see tab. 4) higher antiserum dilutions were used. At the same time the amount of tritiated nandrolone was decreased in order to keep the maximum binding $\left(\mathrm{B}_{0}\right)$ constant. The effect of antiserum and tritiated nandrolone concentration is shown in table 4 . The highest sensitivity $(0.2 \mathrm{nmol} / 1$; read at $80 \%$ binding) was obtained at the highest antiserum dilution and the lowest tritiated nandrolone concentration.

$$
\text { ?..... } \cdot
$$

Tab. 4. Effect of various antiserum and tritiated nandrolone concentrations on the radio-immunoassay sensitivity.

\begin{tabular}{|c|c|c|c|c|}
\hline \multirow{2}{*}{$\begin{array}{l}\text { Amount of } \\
{\left[{ }^{3} \mathrm{H}\right] \text { nan- }} \\
\text { drolone } \\
(\text { pmol/ } \\
100 \mu \mathrm{l})\end{array}$} & \multirow[t]{2}{*}{$\begin{array}{l}\text { Antiserum } \\
\text { dilution }\end{array}$} & \multirow[t]{2}{*}{$\begin{array}{l}\text { \% Binding } \\
\left(\mathrm{B}_{0}\right)\end{array}$} & \multicolumn{2}{|c|}{$\begin{array}{l}\text { Sensitivity } \\
(\mathrm{nmol} / \mathrm{l})\end{array}$} \\
\hline & & & $\begin{array}{l}50 \% \\
\text { binding }\end{array}$ & $\begin{array}{l}80 \% \\
\text { binding }\end{array}$ \\
\hline 0.1 & $1: 28000$ & 38.5 & 0.7 & 0.2 \\
\hline 0.4 & $1: 10000$ & 42 & 2.4 & 0.4 \\
\hline 1.5 & 1: 3500 & 40.5 & 9.5 & 1.6 \\
\hline
\end{tabular}

\section{Reproducibility}

\section{Bound/free separation}

Firstly the reproducibility of the radio-immunoassay part of the assay was checked. The bound/free separation step was found to play an important role in this respect. Optimal conditions for this separation step were assessed by investigating the effect of both incubation time and Norit A concéntration. 
As can be seen from table 5 there is a clear decrease in maximum binding $\left(B_{0}\right)$ at longer incubation times with the highest concentrations of Norit $A$. At the lowest Norit $A$ concentration the $B_{0}$ values remained more or less constant. The non-specific non-binding $\left(B_{g}\right)$ of dextran coated charcoal diminished at longer incubation times and was inversely related to the dextran coated charcoal concentration. The precision, expressed as standard deviation (SD) of the $\mathrm{B}_{0}$ values, ranged from $1-7 \%$. For the final dextran coated charcoal system a concentration of $0.5 \mathrm{~g} / 1$ and an incubation time of $10 \mathrm{~min}$ were chosen, as under these conditions a rather high $\mathrm{B}_{0}$ value was accompanied with a low $\mathrm{B}_{\mathrm{g}}$ value and a low standard deviation.

Tab. 5. Effect of incubation time and Norit A concentration on the bound/free separation step with dextran coated charcoal.

\begin{tabular}{|c|c|c|c|}
\hline \multirow[t]{2}{*}{ Incubation time } & \multicolumn{3}{|c|}{ Norit A concentration } \\
\hline & $0.25 \mathrm{~g} / 1$ & $0.5 \mathrm{~g} / 1$ & $1.0 \mathrm{~g} / \mathrm{l}$ \\
\hline $0 \min \begin{array}{l}B_{g} \pm S D \\
B_{0} \pm S D\end{array}$ & $\begin{array}{l}35.3 \pm 2.4 \% \\
35.2 \pm 7 \%\end{array}$ & $\begin{array}{l}22.1 \pm 6 \% \\
41.3 \pm 7 \%\end{array}$ & $\begin{array}{c}8.2 \pm 16 \% \\
46.0 \pm 4.5 \%\end{array}$ \\
\hline $5 \min \begin{array}{l}B_{g} \pm S D \\
B_{0} \pm S D\end{array}$ & $\begin{array}{l}17.5 \pm 11.5 \% \\
38.5 \pm 3.5 \%\end{array}$ & $\begin{array}{r}7.4 \pm 4.5 \% \\
39.1 \pm 4.5 \%\end{array}$ & $\begin{array}{cl}3.3 \pm & \pm 3 \% \\
36.5 & \pm 2.5 \%\end{array}$ \\
\hline $10 \min \begin{array}{l}B_{g} \pm S D \\
B_{0} \pm S D\end{array}$ & $\begin{array}{l}10.5 \pm 5.5 \% \\
38.1 \pm 6 \%\end{array}$ & $\begin{aligned} 4.7 & \pm 8.5 \% \\
36.6 & \pm 1 \%\end{aligned}$ & $\begin{array}{c}2.6 \pm 9 \% \\
29.5 \pm 6.5 \%\end{array}$ \\
\hline $20 \min \begin{array}{l}B_{g} \pm S D \\
B_{0} \pm S D\end{array}$ & $\begin{array}{c}6.4 \pm 2 \% \\
36.0 \pm 3.5 \%\end{array}$ & $\begin{array}{r}3.6 \pm 4 \% \\
31.3 \pm 3 \%\end{array}$ & $\begin{aligned} 2.3 \pm & \pm .5 \% \\
26.0 \pm & \pm .5 \%\end{aligned}$ \\
\hline
\end{tabular}

\section{Temperature}

The temperature at which the samples are evaporated and dissolved in assay buffer after column chromatography was found to affect not only the percentage recovery but also the precision of the assay procedure. Artificial samples were prepared consisting of tritiated nandrolone in ethyl acetate/isooctane. The samples were evaporated under nitrogen and dissolved in assay buffer both at $25^{\circ} \mathrm{C}$ and at $40^{\circ} \mathrm{C}$. The results àre presented in table 6 . The highest precision, together with the highest recovery were attained at temperatures of $25^{\circ} \mathrm{C} / 40^{\circ} \mathrm{C}$ for evaporation/dissolution respectively.

Tab. 6. Effect of temperature on recovery and precision.

\begin{tabular}{rlll}
\hline Sample Nos. & Evaporation & Dissolution & $\begin{array}{l}\text { Recovery } \\
\text { (fraction) } \pm \text { SD }\end{array}$ \\
\hline $1-12$ & $25^{\circ} \mathrm{C}$ & $25^{\circ} \mathrm{C}$ & $1.01 \pm 0.04$ \\
$13-24$ & $25^{\circ} \mathrm{C}$ & $40^{\circ} \mathrm{C}$ & $1.02 \pm 0.02$ \\
$25-36$ & $40^{\circ} \mathrm{C}$ & $25^{\circ} \mathrm{C}$ & $0.88 \pm 0.08$ \\
$37-48$ & $40^{\circ} \mathrm{C}$ & $40^{\circ} \mathrm{C}$ & $0.91 \pm 0.08$ \\
\hline
\end{tabular}

\section{Within-assay variation}

A value of $9.8 \%$ was found for the within-assay coefficient of variation determined from duplicate measurements of a number of sera from male and female individuals $(n=114)$ from clinical studies.

\section{From day to day variation}

The from day to day variation was derived from values found for a standard serum (normal human serum to which $3.6 \mathrm{nmol}$ nandrolone per liter was added) determined on 13 different days. For duplicate determinations a from day to day coefficient of variation of $12.9 \%$ was found.

\section{Discussion}

The most specific antisera for testosterone (which differs from nandrolone only at position 19) were obtained by coupling derivatives of the steroid molecule to bovine serum albumin at position 3 or 11 . An identical procedure was therefore followed for preparation of nandrolone antisera. However, high crossreactions were observed towards testosterone, dihydrotestosterone and dihydronandrolone for both types of antisera. As the titres of antisera to the 3oxime conjugate were, in general, higher than those of antisera to the 11-hemisuccinate conjugate, the former were chosen for further experiments.

Much lower cross-reactivities towards testosterone and dihydrotestosterone have been reported in the literature (7-10) for antisera raised against 3- and 17-derivatives of nandrolone; for one 17-antiserum no cross-reaction towards testosterone could be detected at all (9). The radioimmunoassays of nandrolone described in the literature (7-14) are mainly used to detect unlawful drug use in sporting events, which requires a high specificity and an easy assay performance.

Our aim was to measure nandrolone levels in clinical studies with Durabolin ${ }^{\circledR}$ or Deca-durabolin ${ }^{\circledR}$, as well as the effect of these compounds on endogenous hormone levels. Therefore, we looked for a suitable separation technique for nandrolone and the major cross-reacting steroids, which would enable us to measure both nandrolone, testosterone and dihydrotestosterone in the same serum extract.

Separation of nandrolone and testosterone in particular is by no means easy, due to the structural similarity of the two compounds. On the basis of the 
good results obtained in other steroid radio-immunoassays (15), Celite/ethylene glycol columns were used for this separation step. The separation between nandrolone and testosterone proved to be markedly affected by the percentage ethyl acetate in the eluent isooctane as well as by the humidity of the column mixture. These parameters were therefore rigidly controlled in other experiments. A complete separation could be achieved with a column mixture dried over phosphorus pentoxide and elution with a mixture of $1 \mathrm{ml}$ ethyl acetate in $99 \mathrm{ml}$ isooctane, followed by a subsequent elution of the nandrolone fraction with a mixture of $10 \mathrm{ml}$ ethyl acetate in 90 $\mathrm{ml}$ isooctane.

The recovery of the test procedure was checked with both tritiated and unlabelled nandrolone. Using tritiated nandrolone, dissolved in assay buffer, we found a recovery (fraction) of $0.87(n=6)$ after extraction and chromatography. Recoveries for unlabelled nandrolone added to buffer $(3.65 \mathrm{nmol} / \mathrm{l})$ as well as to plasma $(1.82-3.65-7.30-14.60 \mathrm{nmol} / \mathrm{l})$ were between 0.84 and 1.01 (fractions).

With the particular antiserum used the highest sensitivity (read at $80 \%$ binding) that could be attained under optimal conditions was $0.2 \mathrm{nmol} / \mathrm{l}$. It may be possible to improve this sensitivity by using radioactive tracers with a higher specific activity. The latter can be accomplished by introduction of a higher number of tritium atoms into the nandrolone molecule $(8)$ or by iodination of nandrolone derivatives (9).

\section{References}

1. Bosch, A. M. G., den Hollander, F. C. \& Woods, G. (1974) Steroids 23, 699-711.

2. Bosch, A. M. G. (1977) Acta Endocrinol. Suppl. 212, 224.

3. Dawson, E. C., Denissen, A. E. H. C. \& van Weemen, B. K. (1978) Steroids $31,357-366$.

4. Goodwin, J. F. \& Choi, S. Y. (1970) Clin. Chem. 16, 24-31.

5. Siiteri, P. K. (1963) Steroids 2, 687-712.

6. Abraham, G. E. (1969) J. Clin. Endocrinol. Metab. 29, 866870.

7. Hampl, R. \& Starka, L. (1979) J. Ster. Biochem. 11, 933936.

8. Hampl, R., Picha, J., Chundela, B. \& Starka, L. (1979) J. Clin. Chem. Clin. Biochem. 17, 529-532.
The assay precision proved to be affected by the temperature at which the samples were evaporated and dissolved in assay buffer. Optimal results were obtained at temperatures of $25^{\circ} \mathrm{C}$ and $40^{\circ} \mathrm{C}$ respectively. Another improvement of precision was achieved by optimisation of the bound/free separation step with dextran coated charcoal.

The within-assay precision was derived from duplicate determinations of different plasma samples $(n=$ $114)$. In this way a within-assay coefficient of variation of $9.8 \%$ was found. The from day to day coefficient of variation was determined by assaying a standard serum, containing $3.65 \mathrm{nmol} / 1$ nandrolone, on different days $(n=13)$. For duplicate determinations a from day to day variation coefficient of $12.9 \%$ was found.

Both values are in agreement with results normally found for steroid radio-immunoassays. On the basis of the results presented in this paper we conclude that our radio-immunoassay of nandrolone is sufficiently specific, sensitive and reproducible to allow adequate measurement of nandrolone in serum or plasma.

\section{Acknowledgements}

The excellent technical assistance of Mr. J. van Casteren and Mrs. $B$. Rutjes is gratefully acknowledged.
9. Brooks, R. I., Jeremiah, G., Webb, W. A. \& Wheeler, M. (1979) J. Ster. Biochem. 11, 913-917.

10. Brooks, R. V., Firth, R. G. \& Summer, N. A. (1975) Br. J. Sports Med. 9, 89-92.

11. Jondorf, W. R. \& Macdougal, D. F. (1977) Vet. Rec. 100, $560-512$.

12. Jondorf, W. R. (1977) Xenobiotica 7, 671-681.

13. Jondorf, W. R. \& Moss, M. S. (1977) Br. J. Pharmacol. 60, 297P.

14. Jondorf, W. R. \& Moss, M. S. (1978) Xenobiotica 8, 197296.

15. Abraham, G. E., Swerdloff, R., Tulchinsky, D. \& Odell, W. D. (1971) J. Clin. Endocrinol. 32, 619-624.
Drs. A. M. G. Bosch

Diagnostics Research Laboratories Organon Scientific Development Group P.O.Box 20

NL-5340 BH Oss 